\title{
The SPaCe Between
}

\section{Mauricio López Noriega*}

Se llama su otro nombre sufrimiento

-porque el amor no es fácil-

dolor de conocer los pozos ciegos:

¿al final algo llega o permanece?

¿cómo adquiere otras manos el silencio?

Este irse deshojando es un saber

del perfume un rumor puntos de fuga

mirar con ojos nuevos.

Nada del niño Amor nos es ajeno y lo ignoramos todo, serpiente dulceamarga, incombatible, pequeño dios que sin preguntar quema y salva sin buscarlo.

Y llegaron las noches, y la Noche se convirtió en el arma inesperada hecha de plata pura y de mentiras que esperaban nacer, ir a una guerra que nunca se libró: ya nos mecían las copas del futuro entre sus brazos, la luna nos abrió los corazones, estábamos marcados.

* Departamento Académico de Estudios Generales, ITAM. 
Señal de fuego, sello de los enamorados toda la piel resulta, límpido sol, ventana de nuestro mejor yo:

es amor que quiere ser la materia de tu miedo, temor de ser en el otro lo que, solo, es incompleto.

¿Por qué

-me pregunto tantotanta trinchera en el mar tanto andar de rama en rama sin decidirte? "No sé", respondes y es un aroma que anega, que hace surgir de dentro los puertos grises del espíritu, horizonte que no distingue agua o nube ni pedregal ni la espuma que haces brotar cuando estás.

¿Por qué me pregunto tanto si tanto vale soñar? Cuántos poemas ya muertos cobran vida si eres tú. Quiero que es gran besar nocturno, siempre escondido, tuviera ya su final; 
apropiarme de las calles de la ciudad en que habito y entregártelas radiantes todas cargadas de ser el lugar que viviremos a pleno sol algún día, esculpiendo fabricando horas más bellas, seguras redimidas por la luz.

Quiero olvidar el refugio de la fuga; quiero ya no guarecerme entre miles de artilugios, de frágiles 'llegarán días más altos y nuestros': nunca más.

Enredadera de fuego destello que, descubierto, se aminora, se adelgaza por los puentes de tu cuerpo hasta encontrarse en mi piel, faro entre nieblas, linterna con vocación de bajel, tiempo de vigilia, alarma que perdemos sin querer:

desnuda eres tan bella como el fin de los tiempos. 
Fragantes, se parecen tanto a ti los nombres de los rituales, las honras, los sacrificios que se revelan de pronto elevando una mañana los ojos al cielo abierto que cubre a la mar en calma palpitante procesión de primavera sin fin.

Y llegarán otros ojos que me busquen, otros cuerpos se acercarán a mi lado mas no me verán a mí: han de encontrar una llama que en mi frente resplandezca noche o no

única rosa entre rosas como cada letra cierta con que compongo tu nombre, espejo de luna, luz abierta a todo mirar, reflejo y canción mis ojos iluminados por ti por tu filiación de sol: no te conocen así sin defensas aprendidas abierta a la inmensidad de la tersura de un tiempo que apenas pensamos ya. 
El espacio entre los dos se llena de travesías que emprendemos sin saber; a la vuelta de una esquina puedo encontrarme tus labios o una ausencia imprevisible después de tanto buscar entre las horas azules en que estás lejos de mí.

¿Valdría la pena cambiarlo si algo pudiera ser más? ¿Pesará más el pasado si ha de volverse a esperar?

Este espacio se convierte en presente porvenir, un suave fluir de ríos que aguardan por mí, por ti dócil remanso del viento bahía para el corazón, columna de humo en el día $\mathrm{y}$, en las noches, un fulgor. 